\title{
Collaborative Leadership Of Wali Nagari In Mitigation Of The Covid-19 Pandemic In Nagari Rancak
}

\author{
Syamsurizaldi ${ }^{1}$, Ria Ariany ${ }^{2}$, Annisa Aulia Putri ${ }^{3}$ \\ ${ }^{1}$ Department of Public Administration in Andalas University, Indonesia \\ 2 Deparment of Public Administration in Andalas University, Indonesia \\ ${ }^{3}$ Master of Public Administration, Andalas University, Indonesia \\ Corresponding Author: syamsurizaldi@soc.unand.ac.id \\ doi) $h t t p: / / d x . d o i . o r g / 10.18196 / j g p p .811341$
}

Article Info:

\begin{abstract}
The COVID-19 Pandemic has struck many countries, including Indonesia. The Indonesian government has created and implemented various policies in dealing with this epidemic, from the central government to the villages. The COVID-19 pandemic response at the local level is regulated in a Village Minister Circular Number 8 of 2020. In tackling the outbreak at the village level, leadership that can embrace all stakeholders is required. This study examines further the collaborative leadership of Wali Nagari in mitigating the COVID-19 pandemic in Nagari Rancak in West Sumatra Province. The research approach used was qualitative with descriptive analysis. The research was conducted in five villages in West Sumatra Province. Data collection techniques in the form of interviews and documentation. This study concluded that the three Nagari Rancak, namely Nagari Batu Bulek, Nagari Sungayang, and Nagari Pakan Sinayan, did not apply collaborative leadership to the maximum, while the other two Nagaris, namely and, had implemented a collaborative leadership model. With collaborative leadership, the Nagari's Wali (leaders) could cover the limitations to overcome COVID-19 impacts in the village
\end{abstract}

Keyword: Collaborative Leadership; COVID-19 Mitigation ; Nagari Rancak.

\section{INTRODUCTION}

Coronavirus Disease 2019 (COVID-19) is a virus that is easily transmitted and has common symptoms such as fever, cough and fatigue. Its highly contagious nature causes this virus to be declared a new pandemic in the world. COVID-19 was first discovered in Wuhan, China, in December 2019. Currently, the COVID-19 has become a pandemic affecting many countries globally.

A pandemic is a form of non-natural disaster. One of the most critical possibilities in overcoming this pandemic is educating everyone about this virus's dangers. This education is intended to mitigate so that the transmission of COVID-19 does not increase. In general, there are two forms of disaster mitigation, namely structural and non-structural mitigation (Rahman, 2015). In dealing with the COVID-19 pandemic, the most likely mitigation is non-structural mitigation because this disaster is categorized as non-natural, and public awareness of the dangers of this virus is urgently needed, considering that currently, the government is also preparing to enter a new normal era while waiting for the discovery of a vaccine. Therefore, awareness and obedience from the community are needed to minimize the spread of the COVID19 pandemic.

Serious efforts of the government in tackling COVID-19 have started from the central government to the village level. As a guideline in mitigating COVID-19 at the village level, the Minister of Village, Development of Disadvantaged Areas, and Transmigration issued a Minister Circular Number 8 of 2020 concerning COVID-19 Response Villages Affirmation of Village Cash Workforce. The COVID-19 response village is intended for the prevention and control of COVID19 in the Village, while the Village Cash Workforce program is intended to strengthen the foundations of the village economy during a pandemic. 
The response to this policy in each village will undoubtedly vary significantly due to each village's different conditions, both from the socio-economic and cultural aspects and to what extent the village community feels the direct and indirect impacts of COVID-19. From Minister Circular Number 8 of 2020, village volunteers' formation is led directly by the headman. Therefore, in implementing the COVID-19 handling policy at the village level, it is suspected that it is also very much influenced by the village head's leadership factor because the task force or village volunteers that are formed will involve all parties in the village.

The COVID-19 Response Village will not be realized if there is no cooperation of all parties at the Village level. The figure of a leader, in this case, the headmen, is very much needed to be able to manage cooperation with all elements in society in the COVID-19 mitigation process. Therefore, adopting a collaborative leadership model is urgently needed in response to the COVID-19 pandemic, so the research of how village heads collaborate and collaborate with stakeholders in response to COVID-19 is essential to do.

The involvement of all elements in society makes leaders need new strategies in their leadership. There is a new paradigm in leadership, namely collaborative leadership. Goman states that: "Some of the benefits of collaborative leadership are creating inclusive environments that energize teams, and release creativity" (Timothy, 2015). Collaborative leadership can provide positive energy to the team and will bring out new creativity from the stakeholders involved. The role of leadership in collaborative government is to help stakeholders find win-win solutions (Wargadinata, 2016).

There have been many studies related to collaborative leadership. This research departs from the implementation of collaborative governance. Chrish Anshell and Alison Gash state that leadership is a factor that influences collaborative success. They develop a collaborative governance model with collaborative processes as the main element influenced by leadership and institutions in achieving the desired results (Ansell \& Gash, 2008). Anshell and Gash, in their research entitled Steward, Mediator, and Catalyst: Toward a Model of Collaborative Leadership, state that leadership is an essential variable in explaining the success or failure of collaborative governance. In this study, collaborative leadership must play a role as a servant, mediator, and catalyst (Ansell \& Gash, 2012).

De Meyer's research entitled Collaborative Leadership: New Perspective in Leadership Development states that four keys describe future leadership, namely collaboration, being able to listen, influence, and adapt. Therefore, in implementing collaborative leadership, the following things need to be prepared: (1) getting the right mindset, (2) reducing transaction costs, (3) looking beyond organizational boundaries, (4) building consensus, (5) ability to create networks, (6) managing duality (De Meyer, 2010).

Research on collaborative leadership was also conducted by Heather Getha-Taylor and Ricardo S. Morse, with the research title Collaborative Leadership Development for Local Government Officials: Exploring Competencies and Program Impact. Taylor and Morse argue that when collaborative governance continues to coalesce into a dominant framework or even a paradigm for public administration in general (and local government in particular), it is necessary to pay attention to the leadership development needs of individuals who implement collaborative governance (Getha-taylor \& Morse, 2016). Therefore, collaborative leadership is urgently needed in managing collaborative governance.

Several previous studies also found that leadership was an essential element in disaster management. Ketaren found a similar concept of leadership in disaster management. When the leadership concept does not meet the criteria needed for disaster management, the emergency response command system will not work in disaster management. Leadership is needed in managing existing social capital. Leaders must synergize with the community to help with disaster management (Yuniarti \& Saty, 2019).

Leadership is a critical element in countermeasures for COVID-19 (Antonakis, 2020; Kaul, Shah, \& El-Serag, 2020; Nicola et al., 2020; Shingler-Nace, 2020; Wilson, 2020). There are five elements to successful leadership during this crisis: stay calm, communication, collaboration, coordination, and providing support (Nicola et al., 2020; Shingler-Nace, 2020). Leaders have to manage these elements, learn new lessons along the way and help develop various creative 
problem-solving strategies to keep their enterprise operational and our patients safe and well cared for (Kaul et al., 2020).

All levels of government carry out the response to the COVID-19 pandemic in Indonesia. Many impacts caused by this virus caused the central government to issue more than 40 policies in less than a month. However, if traced back, the government element that is closest to the community is the village / Nagari government. However, the condition of the Nagari government is different from that of the regency/city government. Nagari has a limited structure, where there are no agencies to assist the government. Nagari only has community institutions and community leaders who are expected to have high participation. With these limitations, in dealing with COVID-19, Wali Nagari must take advantage of existing institutions and community leaders. Research from Syamsurizaldi et al. shows that community or people are the elements that must be managed in response to COVID-19 (Syamsurizaldi, Putri, Sari, Ali, \& Silfiana, 2021). A Wali Nagari leadership style is needed to collaborate with all existing elements and manage many elements.

This study will analyze the collaborative leadership model of Wali Nagari in overcoming COVID-19 in Nagari Rancak. Nagari Rancak is an accomplished Nagari accustomed to carrying out village development by involving all village elements. If Nagari Rancak can take advantage of institutions and community leaders as development potential under normal conditions, is it still possible to use these elements in the COVID-19 pandemic condition? This research is a form of a test case to see how the village guardian can collaborate with institutions and community leaders in response to COVID-19. From some of the literature and phenomena above, this study will look at Wali Nagari's collaborative leadership in mitigating the COVID-19 outbreak in Nagari Rancak in West Sumatra Province.

\section{Collaborative Leadership}

According to Joseph C Rost, leadership is a relationship of mutual influence between leaders and followers who want real change that reflects common goals (Rohim, 2018). Leadership involves a deep relationship of influence, which occurs between people who want significant change, and that change reflects a common goal that the leader and his followers share. Influence means that the relationship between the leader and his followers is not passive but reciprocal and without coercion. Thus, leadership itself is a process of mutual influence.

Meanwhile, collaborative leadership is a concept that refers to how a leader influences someone who works with him to achieve mutually beneficial and practical cooperation goals. Adigium is suitable for the foundation of collaborative leadership by Kozes and Posner, namely, "leadership is not a solo act, it's a team effort" (Wargadinata, 2016). Leadership is not an act alone, but an act or a team effort. The challenges to leaders today are different from those of the past. Increasing public knowledge, along with a shift in social values, made the relationship between the leader and the community no longer based on feudalism.

Collaborative leadership is not intended to design strategies to solve problems but create strategic synergies among stakeholders to lead to innovative solutions, at the level of collaborative governance in contrast to other cooperation, not a complete discharge of duties $\mathrm{s}$ alone but to find new ways to solve problems. According to Mandel and Keist, leaders must act as catalysts and facilitators, build interdependence and not act authoritatively. Leadership does not refer to one particular individual but refers to the process of how each party can interact with each other in new ways that take advantage of each other to increase their respective capacities.

Several studies on collaborative leadership have focused on the personal characteristics of leaders. Goldsmith and Egger identified the following characteristics of collaborative leadership success: broad-minded and open-minded, able to direct, have mediation and negotiation skills, analyze risk, contract management, think strategically, interpersonal communication, and build a team (Timothy, 2015). Meanwhile, according to Foster-Fishman, the core of other collaborative leadership is establishing communication, resolving conflicts, understanding members' mindset, and having problem-solving expertise (Timothy, 2015).

In response to COVID-19, leadership is one of the most critical elements. The involvement of various parties in responding to the COVID-19 pandemic at the local level shows that

39 | Syamsurizaldi ${ }^{1}$, Ria Ariany ${ }^{2}$, Annisa Aulia Putri ${ }^{3}$ 
collaborative leadership must be carried out under certain conditions. Soonhee Kim outlines eight conditions for implementing collaborative leadership at the local level: clear vision, innovation, creativity and flexibility, commitment, transparency, vertical and horizontal collaboration, employee awareness, partnership, and performance achievement (Kim, 2010).

\section{Mitigation of the COVID-19 Pandemic}

COVID-19 is a non-natural national disaster that has occurred in many countries around the world, including Indonesia. This disease is contagious through breathing from people exposed to this virus (Nugraha, 2020). The COVID-19 pandemic harms health and society's social and economic structure. The government has issued various policies to overcome this pandemic and restore everyday life to the people by issuing a new normal policy.

The new normal policy is one of the government policies to return to normal people's lives during a pandemic, but by implementing various health protocols. However, this policy can increase the spread of COVID-19 if implemented without implementing health protocols. Therefore, the government must mitigate the spread of COVID-19 in the middle of the new normal era.

Disaster mitigation is one part of disaster management. Mitigation is a series of efforts to reduce disaster risk through physical development and awareness and increased capacity to face disaster threats (Sunarti, 2018). Sylves argues that mitigation includes decisions related to the community's health, safety, and welfare issues, determined and implemented as a risk reduction program (Wardyaningrum, 2014). Mitigation can take the form of structural and non-structural mitigation. Structural mitigation is an effort taken to reduce disaster risk by reducing vulnerability or increasing the ability to face disasters by building infrastructure. Meanwhile, non-structural mitigation is an effort made to reduce disaster risk by reducing vulnerability or increasing the ability to face disasters by increasing the government and society's capacity in dealing with disasters (West Sumatra Governor Regulation Number 18 of 2008).

\section{RESEARCH METHOD}

The approach used in this study is qualitative. According to Bodgan and Taylor, qualitative research is a research procedure that produces descriptive data in the form of written words from the behavior of the people being observed (Moleong, 2010). This type of research is descriptive analysis, collecting and compiling data, then analyzing and interpreting it. This approach and type were used because the researchers wanted to explain and describe the collaborative leadership of Wali Nagari Rancak in West Sumatra Province. The data used in this study were primary data and secondary data. Primary data is the leading data obtained directly from informants, while secondary data is obtained from documentation and archives related to research. Primary data collection techniques used interviews, while secondary data in this study were documents, news, and other official documents.

This research was conducted in 5 Nagari, the winners of the provincial level achievement villages from 2015-2019. The reason for choosing the research location was because these Nagaris had won the Nagari achievement competition since the implementation of Law Number 6 of 2014 concerning Villages. The five Nagari are in Table.1:

Table.1 List of Nagari Rancak 2015-2019

\begin{tabular}{llll}
\hline Year & Nagari & district & Regency \\
\hline 2015 & Sungayang & Sungayang & Tanah Datar \\
2016 & Batu Bulek & Lintau Buo Utara & Tanah Datar \\
2017 & Sungai Nyalo IV Koto Mudiak & Batang Kapas & Pesisir Selatan \\
2018 & Pakan Sinayan & Banuhampu & Agam \\
2019 & Taram & Harau & Lima Puluh Kota \\
\hline
\end{tabular}

Source: Community and Village / Nagari Empowerment Service of West Sumatra Province, 2020 


\section{RESULT AND DISCUSSION \\ Nagari Readiness and COVID-19 Pandemic Mitigation Strategies in Nagari Rancak}

COVID-19 has been a national disaster that has attack Indonesia since March 2020. This pandemic is categorized as a non-natural disaster and spreads through contagious, primarily through the breathing of people exposed (Nugraha, 2020). The COVID-19 pandemic harms health and society's social and economic structure. In dealing with the COVID-19 pandemic, the government has drawn up a strategy for handling it. This strategy was taken to reduce the impact caused by COVID-19.

A COVID-19 pandemic is a form of non-natural disaster. As a form of emergency response to disasters, the government must compile reasonable disaster management. According to Government Regulation Number 21 of 2008 concerning Disaster Management: "Disaster Management includes pre-disaster, emergency response and post-disaster stages. Pre-disaster activities include mitigation and preparedness activities. Activities during a disaster are in the form of emergency response activities and post-disaster activities in recovery activities (Aryo \& Lubis, 2014).

The first activity that must be prepared in response to the COVID-19 pandemic is disaster mitigation. It is a series of efforts to reduce disaster risk through physical development and awareness and increased capacity to cope with disasters (Sunarti, 2018). Mitigation can be structural and non-structural. Structural mitigation is a means of reducing disaster risk by reducing vulnerability or increasing the ability to cope with disasters by building infrastructure. Meanwhile, non-structural mitigation reduces disaster vulnerability by increasing the government and society's capacity in dealing with disasters. In dealing with the COVID-19 outbreak in the village, structural and non-structural mitigation was also carried out.

\section{Structural Mitigation}

The COVID-19 pandemic, which is rapidly spreading through touch, has prompted health workers and the government to recommend physical distancing. However, the government must also provide supporting facilities to prevent COVID-19 from spreading, especially in the Nagari. Following the Villages Minister Circular Letter Number 8 of 2020, each village must carry out mitigation activities for the COVID-19 outbreak either by providing supporting facilities or through education and outreach. From observations, in Nagari-Nagari Rancak, there were no positive cases of COVID-19 due to the successful mitigation into the village. In Table 2 , the structural mitigation efforts by Nagari Rancak in overcoming the COVID-19 outbreak are revealed.

From Table 2, Nagari Rancak has conducted mitigation activities by providing supporting facilities to avoid viruses, such as handwashing stations, antiseptics, and PPE supplies. According to Villages Minister Circular, the village government must refocus the budget to overcome the impact of COVID-19, both for purchasing or making supporting facilities or providing aid for economically affected communities. This activity is coordinated by the volunteer teams in Nagari, led directly by the Wali Nagari. Therefore, the Wali Nagari plays an essential role in coordinating the volunteer teams' members, consisting of various Nagari institutions.

\section{Non-structural mitigation}

Besides structural mitigation, Nagari Rancak has also carried out non-structural mitigation to increase public awareness and knowledge of this virus's dangers. Table 3 shows the non-structural mitigation activities in Nagari Rancak. From Table 3, every Nagari performs non-structural mitigation measures to prevent the pandemic of COVID-19 into the village. These activities are generally in the form of activities to educate the public regarding the dangers of COVID-19, such as conducting mobile outreach, socializing to homes, solicitation by PKK cadres, and collaborating with figures in the community as Babinsa, village assistants, and traditional and religious leaders in the village.

However, from Tables 2 and Table 3 , the activities tend to be only those required in the Ministry of Circular and lack innovations. The researchers found that the Task Force Team

41 | Syamsurizaldi ${ }^{1}$, Ria Ariany ${ }^{2}$, Annisa Aulia Putri ${ }^{3}$ 
tended to have difficulties and felt afraid to make policy innovations because they did not understand the regulations and were afraid of going against the rules above them. However, there are still Nagari that have made innovations, such as Nagari Batu Bulek, which made an encouraging video to stop the mudik (homecoming) tradition, Nagari Sungai Nyalo IV Koto Mudiak, which collaborated with grocery stores to disburse cash transfer (BLT), and Nagari Taram which collaborated with niniak mamak in community education, PKK and female students to guard border posts during Friday prayers. The implementation of this activity cannot be separated from the Wali Nagari's role as the head of the volunteer team in coordinating its members who are village institutions and stakeholders who are not part of the task force to prevent the COVID-19 pandemic from entering the village jointly.

\section{Collaborative Leadership of Wali Nagari Rancak in Mitigating the COVID-19 Pandemic}

Collaboration at the local level government can be the best alternative when the government is experiencing complex problems. One of the things most needed in applying the concept of collaboration is leadership. Collaborative leadership is essential when the activities carried out involve relations between governments (local-regional-national), relationships between organizations, between sectors, and international organizations (Kim, 2010).

The concept of collaborative leadership can also be applied in response to the COVID-19 pandemic. By incorporating existing values in the community, collaborative leadership can be applied in handling the COVID-19 pandemic at the Nagari level. Referring to Villages Minister Circular No.8 of 2020, the Village Government is obliged to form a Volunteer Team involving all village institutions and led directly by the headman. Therefore, the headmen, also known as Wali Nagari in West Sumatra Province, play an essential role in managing collaboration with all existing institutions.

The formation of the Volunteer Team was also carried out in Nagari Rancak. Apart from the institutions that are members of the volunteer team, headmen must also collaborate with the village actors. Table 4 shows the actors outside the volunteer team who are collaborating in response to the COVID-19 outbreak.

From Table 4, the main actors outside the volunteer teams who are collaborating in response to the COVID-19 outbreak in the village are migrants. In general, Nagari Rancak nomads contributed to PPE provision and assisted families affected by COVID-19 in the village. Even though migrants are not allowed to return to Nagari, they still contribute to helping the Nagari handle the COVID-19 pandemic. Of course, this cannot be separated from the role, commitment, and mutual awareness of the volunteer team, nomads, and other village stakeholders to prevent COVID-19 from entering the village.

Based on Table 4, Nagari Rancak, which involves many stakeholders, is Nagari Sungai Nyalo IV Koto Mudiak and Nagari Taram. One of the causes is the three other Nagari, namely Nagari Sungayang, Nagari Batu Bulek, and Nagari Pakan Sinayan led by PJ Wali Nagari from the District Wali Nagari leads Nagari Sungai Nyalo IV Koto Mudiak and Nagari Taram. PJ Wali Nagari certainly does not fully understand the Nagari conditions because it must be divided between the Wali Nagari and the sub-district employees. However, PJ Wali Nagari indeed continues to communicate and collaborate with the village's task force team members. The following is the collaborative leadership style of Wali Nagari in each Nagari Rancak:

\section{Nagari Sungayang}

PJ Wali Nagari has led Nagari Sungayang since August 2019. Since the entry of the COVID19 pandemic to West Sumatra Province and the issuance of villages Minister Circular Number 8 of 2020, Wali Nagari has instructed institutions in the Nagari to form an anti-Covid volunteer team. Following the Circular, Wali Nagari immediately became the Team Leader of the volunteer team. The volunteer team formation was carried out by utilizing deliberations with existing institutions, including FKPM (community police), Linmas, Karang Taruna, and PKK. At the beginning of the meeting, a common perception was carried out regarding the dangers of the COVID-19 outbreak, and the village guardian began directing the formation of the COVID-19 
Response Task Force. The next step to take is deliberation regarding the distribution of picket schedules and division of labor.

Referring to the conditions for collaborative leadership conveyed by Kim Soon Hee, Wali Nagari Sungayang has been able to equalize perceptions with all institutions involved in response to COVID-19 seen from the task force team's formation through deliberation, which then raises each team's commitment in carrying out their duties. This commitment can be seen from the activities carried out by the task force team, which can be seen in Table.1 and Table.2 and is also evident from the COVID-19 Response Task Force Team in Nagari, who work without payout duties. Such a firm commitment is also caused by the values held by the community, namely togetherness. Therefore, deliberation is made by deliberation, including in determining the community who will receive assistance. Although deliberation is done by deliberation, there are no directions for making programs or activities outside those recommended in a circular. Here, the researchers saw that Wali Nagari could not bring up innovation from the task force team for handling COVID-19 due to the lack of understanding and fear of the Wali Nagari and the Task Force Team to carry out activities against the rules above.

\section{Nagari Batu Bulek}

PJ Wali Nagari has also led Nagari Batu Bulek since November 2019. Like Nagari Sungayang, Nagari Batu Bulek has also formed the COVID-19 Response volunteer team through village meetings. All Nagari institutions are involved in the volunteer team and are directly led by the Wali Nagari. PJ Wali Nagari, who just took office, is facing the challenge of the COVID-19 pandemic. Of course, this must be addressed wisely, starting from building good communication with institutions and understanding the community's needs during a pandemic.

Referring to the collaborative leadership concept conveyed by Kim Soon Hee, PJ Wali Nagari Batu Bulek has tried to create a clear vision, which is to respond to the COVID-19 pandemic through village meetings. Even though it is new, PJ Wali Nagari Batu Bulek can adapt and build exemplary communication with other village institutions and stakeholders. With this clarity of vision, the volunteer team's implementation of the COVID-19 epidemic prevention activities can run well seen in Tables 1 and 2. With PJ Wali Nagari's high enthusiasm and ability to coordinate the team, providing education is done not only for the local community but also for migrants. The volunteer team made a video related to the dangers of COVID-19 and appealed to migrants not to return. Because of this, the isolation area that had been provided was not used because there were no returning migrants. Also, the form of reporting carried out by the Volunteer Team was directly reporting to the PJ Wali Nagari and in writing regarding residents who entered the village.

\section{Nagari Sungai Nyalo IV Koto Mudiak}

Wali Nagari led Nagari Sungai Nyalo IV Koto Mudiak for two periods, and period 2 started in 2018. Wali Nagari, who is also one of the people, certainly understands the existing community's conditions and characteristics. Thus, when forming the task force team, Wali Nagari coordinated all existing institutions to be involved.

When viewed through the concept of collaborative leadership conveyed by Kim Soon Hee, the entire task force team already knows this activity's vision, without explanation from the Wali Nagari. However, Wali Nagari invited the niniak mamak in Nagari to have the same perception in overcoming the COVID-19 pandemic. Wali Nagari conveyed a vision related to overcoming this pandemic and then provided prevention education. With this common perception, all stakeholders are committed to preventing this outbreak from entering the village.

A strong commitment can be seen from the activities carried out. Another form of innovation carried out by the team was making an antiseptic spray device before entering the mosque. Besides, every decision to be taken is always discussed with the community and the volunteer team, and decisions will be made together. Wali Nagari Sungai Nyalo IV Koto Mudiak also can collaborate with other stakeholders. As seen from Table 4, Wali Nagari Sungai Nyalo IV Koto Mudiak collaborates with village partner companies, namely Sinergi Air, grocery stores,

43 | Syamsurizaldi ${ }^{1}$, Ria Ariany ${ }^{2}$, Annisa Aulia Putri ${ }^{3}$ 
and village assistants. By establishing good communication and precise coordination, Sinergi Air helps provide food packages to people affected by COVID-19.

\section{Nagari Pakan Sinayan}

PJ Wali Nagari is currently leading Nagari Pakan Sinayan since April 2020. Just taking office, PJ Wali Nagari was immediately faced with the problem of the COVID-19 pandemic. For this reason, following a circular from the Minister Circular, Nagari, Pakan Sinayan also formed a Volunteer Team by way of deliberation. This deliberation was conducted by inviting jorong delegates who would be involved. Selection of the task force team is carried out by selecting people who participate in the deliberations, who are physically healthy.

When viewed through Kim Soon Hee's concept, Wali Nagari Pakan Sinayan has not coordinated the task force team to innovate in preventing the COVID-19 pandemic seen from the activities carried out only those required in the circular. However, Wali Nagari can collaborate and build commitment with village midwives and health cadres to educate the community.

\section{Nagari Taram}

Nagari Taram is a village designated as Nagari Rancak in 2019. One indicator of its success is community-based development. In this case, the values of togetherness in building and overcoming village problems were embedded even before the COVID-19 pandemic. The COVID19 pandemic prevention activities also began with forming a volunteer team directly led by the Wali Nagari. At the meeting, educational activities and shared perceptions related to COVID-19 were immediately held while still paying attention to health protocols.

The leadership of Wali Nagari Taram has implemented the concept of collaborative leadership. Wali Nagari Taram made the volunteer team, and the stakeholders involved voluntarily carry out prevention activities seen from the volunteer team's enthusiasm to carry out prevention activities, which Wali Nagari initially exemplified. One of them is the Wali Nagari voluntarily issuing personal funds to help student programs in preventing COVID-19. Furthermore, Wali Nagari was also able to collaborate with other volunteer team members by Wali Nagari contacting the community who had suspect status. Then, information on the person's development would be forwarded to the volunteer team re-recorded.

The high commitment of the task force team in preventing the COVID-19 outbreak was not only carried out by Wali Nagari but also followed by other teams. One example, during Friday prayers, TP PKK and female students will guard the border so that no residents outside the village participate in the congregational Friday prayers. It was done to prevent the spread of the COVID-19 pandemic in the village. As for reporting, the pandemic Team coordinates with the Wali Nagari every day regarding the activities that have been and will be carried out. Besides, the activities will be displayed at the Wali Nagari office as a form of accountability.

Among the five Nagari Rancak, there are three Nagari which the Responsible Wali Nagari currently leads, and two Nagari led by the definitive Wali Nagari. From the research, the Nagari led by the person in charge of Wali Nagari cannot implement collaborative leadership optimally because the person in charge is a State Civil Apparatus assigned to fill the vacant position in the Nagari. They generally do not come from the village and have limited knowledge and communication with institutions and community leaders. They do not apply a collaborative leadership model in overcoming the COVID-19 outbreak. It has implications for the activities carried out by the volunteer team, only directions according to the Village Minister Circular.

It is different from the two Nagari led by the definitive Wali Nagari, the village's original people. The definitive Wali Nagari is the choice of the community and already knows the condition of the Nagari. They have also been accustomed to interacting with institutions and community leaders. The two Wali Nagari can apply the collaborative leadership model well seen from the number of stakeholders involved in tackling COVID-19 in the village and various activities. Wali Nagari can establish good communication and collaboration with stakeholders to prevent COVID-19 from optimizing in the village. With collaborative leadership, Wali Nagari can cover the limitations they have in dealing with COVID-19 in the village. 


\section{CONCLUSION}

The response to COVID-19 requires serious efforts from all parties, from the central government to the lowest level, namely the village. With the number of actors involved in tackling COVID-19 at the village level, collaborative leadership is needed that can accommodate institutions and community leaders in tackling COVID-19. This study found that the three Nagari Rancak, namely Nagari Batu Bulek, Nagari Sungayang, and Nagari Pakan Sinayan, did not apply collaborative leadership to the maximum. These three Nagaris are led by PJ Wali Nagari, who do not fully understand the Nagari conditions and cannot collaborate with institutions and community leaders. Meanwhile, the two villages, namely Nagari Sungai Nyalo IV Koto Mudiek and Nagari Taram, have implemented a collaborative leadership model in response to COVID19. Wali Nagari from the two villages can manage the village's stakeholders, and the activities carried out are more varied and innovative. With collaborative leadership, Wali Nagari can cover the limitations they have in dealing with COVID-19 in the village.

\section{ACKNOWLEDGEMENT}

Thank you to the Directorate of Research and Community Service, Deputy of Strengthening Research and Development of the Ministry of Research and Technology / National Research and Innovation Agency, for funding research activities through contract letters Number: T / 57 / U.16.17 / PT / 01.03 / PTM-Sosial-Humaniora/ 2020 on March 17, 2020

\section{REFERENCES}

Ansell, C., \& Gash, A. (2008). Collaborative governance in theory and practice. Journal of Public Administration Research and Theory, 18(4), 543-571. https://doi.org/10.1093/jopart/mum032

Ansell, C., \& Gash, A. (2012). Stewards, mediators, and catalysts: Toward a model of collaborative leadership. Innovation Journal, 17(1), 1-21.

Antonakis, J. (2020). Leadership to defeat COVID-19. Group Processes \& Intergroup Relations. https://doi.org/10.1177/1368430220981418

Aryo, B., \& Lubis, R. H. (2014). Kebencanaan dan Kesejahteraan: Konsep dan Praktek. Jakarta: LKPS.

De Meyer, A. (2010). Collaborative Leadership: New Perspectives in Leadership Development. In Working Paper Series. Cambridge: University of Cambridge. https://doi.org/10.1057/9780230295087_3

Getha-taylor, H., \& Morse, R. S. (2016). Collaborative Leadership Development For Local Government Officials. Public Administration Quarterly, 37(1), 71-102. Retrieved from http://www.jstor.org/stable/24371989

Kaul, V., Shah, V. H., \& El-Serag, H. (2020). Leadership During Crisis: Lessons and Applications from the COVID-19 Pandemic. Gastroenterology, 159(3), 809-812. https://doi.org/10.1053/j.gastro.2020.04.076

Kim, S. (2010). Collaborative Leadership and Local Governance. In The Future of Public Administration, Public Management, and Public Service Around The World (pp. 111-117). Washington, D.C.: Georgetown University Press.

Moleong, L. (2010). Metodologi Penelitian Kualitatif. Bandung: Remaja Rosdakarya.

Nicola, M., Sohrabi, C., Mathew, G., Kerwan, A., Al-Jabir, A., Griffin, M., ... Agha, R. (2020). Health policy and leadership models during the COVID-19 pandemic: A review. International Journal of Surgery, 81(May), 122-129. https://doi.org/10.1016/j.ijsu.2020.07.026

Nugraha, aji S. (2020). Kearifan Lokal Dalam Menghadapi Pandemi Covid-19: Sebuah Kajian Literatur. Sosietas, 10(1), 745-753. https://doi.org/10.17509/sosietas.v10i1.26063

45 | Syamsurizaldi ${ }^{1}$, Ria Ariany ${ }^{2}$, Annisa Aulia Putri ${ }^{3}$ 
Rahman, A. Z. (2015). Kajian Mitigasi Bencana Tanah Longsor di Kabupaten Banjarnegara. Gema Publica, 1(1), 1-14. https://doi.org/10.14710/gp.1.1.2015.1-14

Rohim, A. H. A. (2018). Model Kepemimpinan Kolaboratif dalam Membangun Lembaga Pendidikan Unggul. Tesis Pascasarjana UIN Maulana Malik Ibrahim Malang.

Shingler-Nace, A. (2020). COVID-19: When Leadership Calls. Nurse Leader, 18(3), 202-203. https://doi.org/10.1016/j.mnl.2020.03.017

Sunarti, V. (2018). Peranan Pendamping Desa Dalam Membentuk Masyarakat Sadar Bencana Sebagai Salah Satu Mitigasi Bencana. Jurnal Pendidikan, 4(2), 166-182.

Syamsurizaldi, Putri, A. A., Sari, M. V., Ali, M. S., \& Silfiana, W. (2021). Lineage Empowerment as Community Governance Model in Response to the Covid-19 Outbreak in Pasia Laweh Village. 495(ICoSPOLHUM 2020), 56-61. https://doi.org/10.2991/assehr.k.210125.011

Timothy, R. K. (2015). Literature Review on Collaborative Leadership. Literature Review on Collaborative Leadership, 21.

Wardyaningrum, D. (2014). Perubahan Komunikasi Masyarakat Dalam Inovasi Mitigasi Bencana di Wilayah Rawan Bencana Gunung Merapi. Jurnal ASPIKOM, 2(3), 179. https://doi.org/10.24329/aspikom.v2i3.69

Wargadinata, E. (2016). Kepemimpinan Kolaboratif. Jurnal Administrasi Pemerintah Daerah, $8(1), 1-14$.

Wilson, S. (2020). Pandemic leadership: Lessons from New Zealand's approach to COVID-19. Leadership, 16(3), 279-293. https://doi.org/10.1177/1742715020929151

Yuniarti, E., \& Saty, F. M. (2019). Pengaruh Komitmen Organisasi Dan Gaya Kepemimpinan Terhadap Hubungan Antara Partisipasi Anggaran Dan Kinerja Manajerial ( Studi Empiris Pada Kantor Cabang Perbankan Di Propinsi Lampung ) The effect of organizational commitment and leadership style towards. Jurnal Ilmiah ESSAI, 2(1), 1-16. 
Table.2 Structural Mitigation Pandemic COVID-19 made by Nagari Rancak in West Sumatra Province

\begin{tabular}{|c|c|c|}
\hline No. & Nagari & Forms of Structural Mitigation \\
\hline \multirow[t]{5}{*}{1} & \multirow[t]{5}{*}{ Sungayang } & Providing sinks at Wali Nagari and Balai offices \\
\hline & & Distributing masks \\
\hline & & Spraying disinfectant \\
\hline & & Providing thermometer gun and PPE \\
\hline & & Distributing cash transfer (BLT) and groceries \\
\hline \multirow[t]{6}{*}{2} & \multirow[t]{6}{*}{ Batu Bulek } & Spraying disinfectant \\
\hline & & Setting up banners \\
\hline & & Distributing masks \\
\hline & & Providing isolation areas \\
\hline & & Distributing cash transfer (BLT) and groceries \\
\hline & & Providing PPE \\
\hline \multirow[t]{5}{*}{3} & \multirow{5}{*}{$\begin{array}{l}\text { Sungai } \\
\text { Nyalo } \\
\text { Koto } \\
\text { Mudiak }\end{array}$} & Providing antiseptics in mosques \\
\hline & & Distributing masks \\
\hline & & Spraying disinfectant \\
\hline & & $\begin{array}{l}\text { Distributing cash transfer (BLT) and groceries in collaboration with the grocery } \\
\text { store }\end{array}$ \\
\hline & & Providing sinks \\
\hline \multirow[t]{4}{*}{4} & \multirow{4}{*}{$\begin{array}{l}\text { Pakan } \\
\text { Sinayan }\end{array}$} & Producing leaflets and pamphlets \\
\hline & & Spraying disinfectant \\
\hline & & Distributing cash transfer (BLT) and groceries \\
\hline & & Providing PPE \\
\hline \multirow[t]{6}{*}{5} & \multirow[t]{6}{*}{ Taram } & Spraying disinfectant \\
\hline & & Providing masks \\
\hline & & Providing PPE \\
\hline & & Distributing cash transfer (BLT) and groceries \\
\hline & & Providing sinks in the Wali Nagari office \\
\hline & & Producing brochures and pamphlets \\
\hline
\end{tabular}


Table.3 Non-Structural Mitigation carried out by Nagari Rancak in West Sumatra Province

\begin{tabular}{|c|c|c|}
\hline No. & Nagari & Non-Structural Forms of Mitigation \\
\hline \multirow[t]{3}{*}{1} & \multirow[t]{3}{*}{ Sungayang } & Socializing with mobile cars \\
\hline & & Guarding the border area \\
\hline & & Measuring body temperature \\
\hline \multirow[t]{7}{*}{2} & \multirow[t]{7}{*}{ Batu Bulek } & Socializing with mobile cars \\
\hline & & Educating the Jorong \\
\hline & & Measuring body temperature \\
\hline & & Guarding the border area \\
\hline & & Making an appealing video to encourage people to stay at home \\
\hline & & $\begin{array}{l}\text { Collaborating with a public health center in community education and } \\
\text { control of migrants returning home }\end{array}$ \\
\hline & & $\begin{array}{l}\text { Going to the residents' houses who have returned to their hometowns and } \\
\text { monitor their conditions }\end{array}$ \\
\hline \multirow[t]{4}{*}{3} & \multirow{4}{*}{$\begin{array}{l}\text { Sungai } \\
\text { Nyalo } \\
\text { Koto } \\
\text { Mudiak }\end{array}$} & Socializing to the Village and Nagari \\
\hline & & Making policies regarding mudik (homecoming) tradition \\
\hline & & $\begin{array}{l}\text { Synchronizing the perception with the } 13 \text { niniak mamak in Nagari to provide } \\
\text { community advice }\end{array}$ \\
\hline & & Providing education to the community through mosque administrators \\
\hline \multirow[t]{2}{*}{4} & \multirow[t]{2}{*}{$\begin{array}{l}\text { Pakan } \\
\text { Sinayan }\end{array}$} & $\begin{array}{l}\text { Disseminating and providing understanding to the community regarding } \\
\text { COVID-19 }\end{array}$ \\
\hline & & Providing education by health cadres in the village \\
\hline \multirow[t]{7}{*}{5} & \multirow[t]{7}{*}{ Taram } & Home control by officers \\
\hline & & Personal control by the Nagari guardian \\
\hline & & $\begin{array}{l}\text { Making exercise activities and helping the force team provide BLT to } \\
\text { community homes }\end{array}$ \\
\hline & & $\begin{array}{l}\text { Conducting meetings with niniak mamak while still implementing health } \\
\text { protocols for COVID-19 education }\end{array}$ \\
\hline & & $\begin{array}{l}\text { Cooperating with Babinsa to appeal, either directly to homes or by a patrol } \\
\text { car }\end{array}$ \\
\hline & & $\begin{array}{l}\text { Cooperating with } P K K \text { and female students to guard the border during Friday } \\
\text { prayers }\end{array}$ \\
\hline & & Conducting outreach at tourist attractions and markets \\
\hline
\end{tabular}


Table.4 Actors - Actors who collaborate in Nagari in response to the COVID-19 outbreak

\begin{tabular}{lll} 
No. & Nagari & The actors involved \\
\hline 1 & Sungayang & $\begin{array}{l}\text { Team Leader: Wali NagariDeputy: Chairman of BPRN Sungayang } \\
\text { Member: }\end{array}$
\end{tabular}

1. Villages government employee

2. BPRN members

3. Jorong

4. Karang Taruna

5. TP PKK

Partners: Perantau, Public Health Centre

\begin{tabular}{lll}
\hline 2 & Batu & Team Leaders: Wali Nagari \\
& Bulek & Deputy: Chairman of BPRN Batu Bulek \\
& Member:
\end{tabular}

1. Village Government Employee

2. BPRN members

3. Jorong

4. Village Local Assistants

5. PKH Facilitator

6. Village Fund Assistant

7. Village Midwives

8. Religious leaders

9. Traditional Figures

10. Public figure

11. Youth organization

12. TP PKK

13. Village Community Mobilizer Cadres

14. Nagari Disaster Task Force

15. Nagari Elementary Institution

16. FKPM, Satlinmas

Partners: Babinkamtibmas, Babinsa, Village Facilitators, Perantau, Public Health Centre

\begin{tabular}{lll}
\hline 3 & Sungai & Team Leader: Wali Nagari \\
Nyalo IV & Deputy: Chairman of BPRN Sungai Nyalo IV Koto Mudiak \\
Koto & Member: \\
Mudiak & 1. Village Government Employee \\
& 2. BPRN members \\
& 3. Jorong \\
& 4. Karang Taruna \\
& 6. LPMN \\
& 6. TP PKK
\end{tabular}

Partners: Perantau, Partner Companies, Grocery Stores, Babinsa

\begin{tabular}{lll}
\hline 4 & Sinayan's & Perantau, Sub public health center, Village Midwives \\
\hline 5 & Taram & Team Leaders: Wali Nagari \\
& & Deputy: Chairman of the Bamus \\
Member: & 1. Village Government Employee \\
2. Jorong \\
3. Bamus members \\
4. Linmas Nagari \\
5. PLD Harau District \\
6. Public figure \\
7. KPMD \\
8. PD of Harau District \\
9. PKK \\
10. Food Cadre \\
11. Village Midwives \\
12. Karang Taruna \\
13. Munag Taram \\
Partners: perantau, Students (Gema), Niniak Mamak, Babinkamtibmas, \\
Mosque Administrators
\end{tabular}

Source: Researcher Process, 2020

49 | Syamsurizaldi ${ }^{1}$, Ria Ariany ${ }^{2}$, Annisa Aulia Putri ${ }^{3}$ 